\title{
Pragmatics Principles of English Teachers in Islamic Elementary School
}

\author{
Gumarpi Rahis Pasaribu \\ STIT Al-Ittihadiyah Labuhanbatu Utara \\ gumarpi19@gmail.com
}

Sholihatul Hamidah Daulay

UIN Sumatera Utara Medan

sholihatulhamidah@uinsu.ac.id

Putra Thoip Nasution

UIN Syarif Hidatullah Jakarta

thoipputra123@gmail.com

*Corresponding Author

Email : gumarpi19@gmail.com, .

DOI: https://doi.org/10.18326/jopr.v4i1.29-40

Copyright $(C)$ The Author (s)

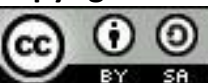

This work is licensed under a Creative Commons Attribution-ShareAlike 4.0 International License.

How to Cite: Pasaribu, G., Daulay, S., \& Nasution, P. (2022). Pragmatic Principles of English Teachers in Islamic Elementary School. Journal of Pragmatics Research, 4(1), 29-40. doi:https://doi.org/10.18326/jopr.v4i1.29-40

\footnotetext{
Submission

Track:

ABSTRACT

Received:

13-12-2021

Final Revision:

01-02-2022

Available online:

02-02-2022

Corresponding

Author:

Gumarpi19@mail.com

This qualitative study presents the research results on Pragmatics politeness in the language of English teachers in Islamic elementary schools. The problem formulation of this research focuses on what and how Pragmatics politeness is in the language of English teachers in Islamic elementary schools. The objectives of this study are (i) to describe the form of Pragmatics speech in the language of English teachers; (ii) to describe the tools used in using Pragmatics politeness in the teacher's language, English. The research approach used is qualitative research. Data were collected from various communication events in teaching English in the classroom between teachers and students by participating in observation techniques, notetaking/recording techniques, and interviews. Structurally, the various sub-illocutions were delivered with one core speech unit alone or with a combination of core speech (TI) and supporting speech units (TD) in the
} 
form of asking questions, commanding acts, and opening speech units (TB) in the form of greetings. Pragmatics politeness speech acts of English teachers and students are generally expressed in imperative sentences (active and passive), declarative sentences, and interrogative sentences. Second, the tools of Pragmatics politeness in the language of English teachers in Islamic elementary schools found in the speech of the teaching process can function as an action stimulator, a request for approval of the action, an invitation.

Keywords: Politeness, Pragmatics, Islamic elementary school.

\section{INTRODUCTION}

In the 21 st century classroom, language teachers are facilitators of student language learning and creators of productive classroom settings in which students can develop the skills in the language learning process. In that case, one of today's principles in language learning is the focus on learning and the learner. However, the real classroom, sometimes, by using technology, shows us that the language learning process has been dehumanized to a certain extent. (Risang, 2017) stated that teachers in the 21st century are technology. (Brown, 2004) stated that the learners inside the 21 st century have created up in a fast-paced automated world and are easily blocked out of the traditional lecture-based homeroom. Inquiring about, conveying, and working from home worldwide by methods for Personal Computer (PC) or Personal Digital Assistant (PDA) can be a no brainer for them. Long-range interpersonal communication goals are just as incredible as their learners' substance.

Language awareness is nearly language and conscious insight and affectability in language learning, teaching, and use. For outline, Language Awareness issues consolidate examining the advantages that can be resolved from making incredible data around vernacular, an insightful comprehension of how language works, and how people learn and use language (Ellis, 2002).

In linguistics, there are two studies, namely the study of language structurally and functionally. In this case, the most appropriate study to see the conversations of teachers and students in learning at MIS Al-Afkari Medan, Pragmatics studies is a study of the intent behind the speech of a speaker and interlocutor that is bound by context. In line with this study of Pragmatics, experts explained that semantic Pragmatics is a context-bound study of language. In the study of Pragmatics, various linguistic features that are bound by context can be found, including social context, time, place, atmosphere, education, and culture. This Pragmatics study concerns aspects of the intent behind someone's speech.

Therefore, speech context is powerful in understanding the meaning of speech in communicating. Therefore, conversations between teachers and students in learning Indonesian use various elocutionary, illocutionary, and perlocutionary speeches acts and contain various meanings behind the speech. Related to the study of the intention behind this speech, Pragmatics studies meaning about speech situations. Referring to this opinion, the role of the speech context greatly determines the intention of the speech in a conversation. 
Polite behavior is quite famous and has become the center of attention of international and national researchers. Several studies related to Javanese polite behavior have been carried out. Errington (1998) examines the structure and style of language related to ethics, etiquette, and politeness in Javanese society from a semiotic and ethical perspective. There is also Smith-Hefner (1998), which examines the symptoms of politeness related to the habits of Javanese women. However, Pragmatics politeness in the language of Islamic elementary school English teachers has not been studied in more depth and detail, especially for language teaching in elementary schools. The conversation between teachers and students in learning is fascinating. It can be seen that the interaction of teachers and students has a positive impact on the communication atmosphere in the classroom. The function of language as a communication tool is essential. Indonesian as a communication tool has four aspects of language skills, namely listening, speaking, reading, and writing skills. These four skills cannot be separated in daily communication.

The second thing is what Pragmatics politeness is and how it is used in the language of English teachers in Islamic elementary schools. So far, research on politeness in education has not explored data carefully. This is what underlies researchers to conduct a study of the Pragmatics politeness of English teachers in Islamic elementary schools. Most of which both teachers and students have cultural backgrounds. This study of Pragmatics politeness in the language of English teachers in Islamic elementary schools is part of a Pragmatics study. This section discusses some of the theoretical concepts relevant to the study's direction in this research. In general, the study of Pragmatics was pioneered in the 1930s by Morris, Carnap, and Pierce, who argued that Pragmatics is part of semiotics, namely the science of signs. Experts give the limitations on Pragmatics studies so far have varied. However, most experts define Pragmatics as the study of meaning about context. Horn and Ward (2007: xi) define Pragmatics as 'the study of those context-dependent aspects of meaning which are systematically abstracted away from in the construction of content and logical form.' construct logical content and form'). Mey (1993:42) states that Pragmatics is the study of conditions of human language uses as the context of society determines these.

Pragmatics is an extensively asked about range in historical background, language acquisition and language learning and educating, and one of the targets of the Common European Framework of Reference for Languages, with a specific place on handy and sociolinguistic capacities, for example, the data of contents or structures of connection, the ability to supervise cooperation, to characterize fitting talk acts or the data and use of social and social markers. (Delahhaie, 2018).

Pragmatics focused on the appropriateness of utterances in different sociolinguistic contexts. Unlike pragma linguistic knowledge that the teacher or the textbooks can easily provide are given, socio-Pragmatics knowledge demands the students' adequate knowledge of the language and its culture. In this case, the teachers should increase the students' awareness of what they know already and encourage them to use their universal or transferable L1 Pragmatics knowledge in L2 
contexts by providing them Pragmatics-oriented materials and activities, such as authentic language samples, role-play, and the model dialogue (Altarawneh, 2020).

A culture-specific science that studies the cultural elements of communities; for, intercultural factors hinder learners' language proficiency due to cultural differences between the native and target language (Gunduz, 2019). Those elements which are covertly expressed throughout linguistic knowledge and communication can be divided into two parts (1) linguistic elements engraved in the grammar, such as lexical and syntactic elements (verbal elements); (2) non-grammatical elements, such as kinesics and proxemics (non-verbal elements).

A sub-branch of Pragmatics is concerned with culture-specific studies. It uncovers the culture-specific background of language learning involving social or sociolinguistic dimensions, like using the rules of speaking. (Kachru \& Smith., 2009)

\section{Politeness Principle}

Politeness Principle is a complement to interpersonal rhetoric that is necessary to be able to fully explain the relationship between the proportional meaning and the Pragmatics power of speech that appears, for example:

A: You invited Kaulan and Syarqawi? (1)

B: Yes, I invite Kaulan.(2)

Viewed from the cooperative principle, utterance (2) implies disobedience to the maxim of quantity because $\mathrm{B}$ does not provide sufficient information. However, from a semantic point of view, this information is not sufficient because the proposition formed in B's utterance is only limited to 'I invite Anton', and there is no proposition that informs about 'is Ali invited too'. Regarding the symptoms of using language like this, Grice (1975) suggests that B tries to communicate non-proportionate meanings called implicatures, i.e., meanings that are conveyed but not said. So, from the behavior of speaking B above, an implicature can be drawn, namely: 'but I did not invite Ali, actually B was able to provide complete and complete information regarding his invitation to Kaulan and Syarkawi. Why did B choose to inform Ali's fate regarding the invitation through implicatures instead of implicatures? The most plausible reason is that B decided to be polite towards his addressee or a third party, Kaulan. Thus, B prefers to comply with PS to maintain social harmony with his partner or third party. This kind of language use phenomenon is related to language politeness behavior.

\section{Leech's Theory of Politeness}

Leech's theory of politeness (1983) is based on a cost-benefit scale. This profit and loss statement is manifested in the maxims of politeness. So, politeness is understood as an effort to minimize losses and maximize the benefits of the speaker Cooperation of Grice (1972). 
In summary, the politeness maxims reflect the scales of (1) cost and benefit, (2) criticism and praise, (3) agreement and disagreement, and (4) sympathy and antipathy. Besides the politeness theory, there is also a speech act which is the smallest unit in communication. The speech act is 'the basic or minimal units of linguistic communication,' namely the basic or most minor communication units (Searle, 1969:16). So in Searle's view, the smallest unit of communication is not a word or sentence as in the view of adherents of formal linguistics, which traditionally views that sentences always contain propositions that are true or false. In Pragmatics, statements are not only 'constant' but also 'performative' in the sense that the speaker does not just say something but he 'does something' (Austin, 1962). When someone says 'I promise to buy clothes for you' or 'I'm sorry for what happened, then he doesn't just say a series of words, but he does an act of promise or an act of apologizing. Austin calls these utterances performative, and verbs such as 'to promise' or 'to apologize' are called performative verbs.

Austin's thinking was further developed by Searle (1969) who clarified three aspects of speech acts, namely locutionary act, illocutionary act, and perlocutionary act. According to Searle, everyone who speaks in a communication event simultaneously performs actions, namely (1) reciting words or sentences (utterance act/locutionary act), (2) referring (referring) to the subject in the speech as well as stating something related. the subject (predicating) in the sentence/speech that is pronounced, after referred to as the propositional act, (3) means something such as ordering, asking, asking, and the like contained in the spoken speech, called the illocutionary act (Searle, 1969: 23-25). The classification of speech acts, according to Searle (1969) is as follows:

\section{Declaration}

This speech act includes words or expressions that can change the world and state of affairs. Some of the verbs related to this speech act are bet, declare, baptize, resign, declare to stop doing something.

\section{Representative}

This speech act is related to stating what the speaker believes to be true. Some of the verbs related to this speech acts are to describe, claim, suspect, urge, predict.

\section{Commissive}

These speech acts are related to words that bind speakers to take action in the future. The verbs associated with this speech act are promised, offer, threaten, refuse, swear, and volunteer.

\section{Directive}

This speech act includes actions where the words used aim to make the speech partner do something. Some of the verbs related to this speech are commanded, beg, invite, forbid, and suggest.

\section{Expressive}

These speech acts are related to actions in which the words express what the speaker feels. Some of the verbs associated with this speech are apology, praise, congratulate, pity, regret. 
In addition to Searle, Kreidler (1998) has a reasonably clear concept of the differences in each category of existing speech acts. Although there are differences in terms and the number of categories of speech acts in his classification, it is substantively not much different from Searle. The types of Kreidler speech acts can be condensed as follows:

\section{Assertive}

This speech act aims to provide information or present facts, data, what is currently existing or what has existed, and what is currently or has happened. Assertive statements are true or false so that they can be verified or falsified by speakers or other people. The conditions for the feasibility of this speech act include, among other things, that the report must be feasible, the speaker is bound to the truth of the information he makes. The speaker considers the speaker's report to be accurate. Various verbs related to this speech act have the following characteristics:

Focus on announcing, declaring, revealing, explaining, suggesting, indicating, mentioning, connecting, reporting, proclaiming.

Focus on the truth of speech such as strengthening, guaranteeing, maintaining, swearing, betting, testing, claiming, convincing, certifying.

Focus on the speaker's commitment or involvement in what is reported, such as emphasizing, hinting, implying, intimate.

\section{Performative}

This speech act has the main characteristic of bringing about changes in world conditions (the state of affairs). The utterances that contain these speech acts are usually sentences with the subject in the first person I or we and use the verb' present tense'. The eligibility conditions for this speech act include, among others, the speaker has the authority to make performative utterances. The time, place, and environment must be appropriate. The speaker recognizes the speaker's authority and the appropriateness of the event. Examples of verbs are baptized, bid in an auction, place a bet, fire, marry off, declare, inaugurate, nominate, make an arrest.

\section{Verdictive}

Speakers carry out this speech act to make an assessment or judgment of the actions of the speaker or other people. Eligibility conditions include:

There is a possibility of action occurring.

The ability of the speaker to act is present.

The sincerity of the speaker in teaching verdicative actions.

The speaker believes that the speaker is sincere.

Verbs related to these speech acts are divided into (a) actions that are seen as positive, namely praising, congratulating, appreciating; (b) actions that are seen as negative, namely: accusing, suspecting, criticizing, blaming, criticizing, berating; and actions that are seen as beneficial to the speaker, such as being grateful, being indebted. 


\section{Directive}

This speech act is an utterance that makes the addressee or not perform an action that is 'future' (prospective). Eligibility conditions include (1) the action has the feasibility to be carried out, (2) the speaker can act, (3) for orders, the speaker acknowledges the speaker's authority, (4) for requests, the speaker has 'hope that the request will be granted. And (5) for suggestions, speakers must make an assessment. The utterance is in the form of a sentence containing the second person pronoun $\backslash$ and as the doer of the action. This speech act includes three types of actions, namely: commands, such as ordering, forbidding, demanding; supplications, such as asking, interested in, pleading, wishing; and suggestions such as suggesting, preferably, advising.

\section{Expressive}

This speech act is an utterance that comes from the speaker's actions. Eligibility conditions include:

The feasibility of the action.

The speaker's ability to act.

The sincerity of the speaker speaks sincerely, and the speaker believes it.

This speech act is related to verbs such as admitting, confessing (guilty/sinful), apologizing, denying, boasting/boasting because it is the speaker's acknowledgment of his past actions (retrospective).

\section{Commission}

This speech act is an utterance that binds the speaker to take any action that will occur in the future (prospective), as stated. The feasibility includes (1) the speaker can take action according to his promise and intends to fulfill it, and (2) the speaker has confidence in the speaker's ability and sincerity in doing so action. Examples of verbs that are included in the speech act are promising, agreeing, offering, refusing, swearing, asking.

\section{Fatis}

This speech act is contained in a speech intended to maintain a sympathetic and close relationship between members of the community with the same cultural background. Eligibility conditions include: (1) speakers and addressees know or practice the same social habits, and (2) speakers and addressees are well acquainted with forms of phatic expressions that have been commonly used in certain social situations to maintain social harmony in their culture. The utterances that contain these speech acts include, among others: greetings of meeting and farewell, polite expressions such as 'thank you, 'you're welcome', polite formal conversation (polite chitchat) about the weather, a person's health, or other things that are common and expected in a society and typical phrases used to congratulate, etc. This study examines the Pragmatics politeness of the English language teacher, who has a teaching background in Islamic elementary 
schools. To capture the meaning of language politeness behavior meant, Researchers need qualitative data in the form of notes with detailed, complete, and in-depth sentence descriptions and do not rely on data in the form of numbers. Data were analyzed with all riches. His character is full of nuances of meaning and is as close as possible to the original form as at the time of recording (Sutopo, 2006).

\section{RESEARCH METHOD}

Library research is a research design to develop an educational product, such as curriculum, syllabus, textbooks, instructional media, modules, and assessment instruction. It is used to develop and validate the product that has been designed in education product. The research approach used in this study is a qualitative descriptive approach to describe the English teacher expressing polite speech to his partner in a communication event. So, the focus of this research is Pragmatics politeness related to the delivery of English speech acts by English teachers with students in Islamic elementary school classes, not the cultural behavior of English teachers as a whole, Borg and Gall (2003).

As mentioned in the background of the problem, this research targets are English teachers and first-grade Islamic elementary school students. The English teacher is part of the educators who teach English at the Islamic elementary school MIS Al-Afkari Batang Kuis Deli Serdang.

The research data that have been collected are (1) various units or series of oral utterances containing Pragmatics politeness used by English teachers in teaching in the classroom, (2) different words, phrases, or clauses used to communicate with students in teaching English in the classroom.

The data collection techniques used in this study include:

Observation, Recording of the interaction process that occurs when the teacher uses English to communicate with Islamic elementary school students, Interviews to obtain data about things that underlie polite behavior.

Pragmatics of the English teacher, especially the use of speech in learning interactions in the classroom, and confirming the temporary conclusions generated through analysis of Pragmatics politeness in English in the classroom (Patton, 1980).

The technique of checking the validity of the data is intended to obtain information that can be accounted for, the researcher uses several techniques, namely (1) the persistence of the researcher, as this qualitative research is fixed, which means that from the beginning the researcher has been given the direction that has been given by the questions formulated as research problems. To obtain data on Pragmatics politeness in the English language teacher's language along with the context, the researcher conducted intensive observations and recordings of the verbal methods used by the English teacher when carrying out acts of ordering, asking, inviting, or advising/suggesting. There are four types of triangulation in qualitative research, namely (1) 
triangulation of data sources, (2) triangulation of researchers, (3) triangulation of methods, and (4) theoretical triangulation (Patton, 1980). The four types of triangulation techniques used in this study are triangulation of data sources and triangulation of data collection methods.

Researchers in the field carried out the data analysis technique simultaneously with the data collection process. At each end of the observation activity, the researcher conducted a preliminary analysis on each data unit in the form of conversational texts that were successfully captured and carried out by following the principles of Miles and Huberman's (1984) analysis model. The application of the analysis of the Miles and Huberman (1984) model is carried out with steps of reducing data, presenting data, and drawing conclusions or verification. Data reduction was carried out when the researcher got a recording of the conversation of an English speaker in the process of collecting data on observation activities in the field. The netted data was transcribed and further reduced by sorting out Pragmatics politeness conversations and set aside. The systematic process to build the empirical basis of design, development, and evaluation to create the instructional and non-instructional products and tools. (Richey \& Klein, 2005).

\section{RESULTS \& DISCUSSION}

After completing the data analysis, the researcher found that Pragmatics politeness utterances in the English language teacher of Islamic elementary school grade 1 can consist of (1) The form of Pragmatics politeness speech in the language of English teachers in Islamic elementary schools consisting of core speech and supporting speech, the form of the core speech based on the framework of Kreidler (1998) and Searle (Mey, 2001), (2) the standard units of speech that make up the overall structure of Pragmatics politeness in the English Teacher's language which has a specific function. From the results of data analysis, it was found that Pragmatics politeness in the language of the English Teacher can contain Pragmatics speech acts. Each utterance in the language of the English Teacher in Islamic elementary schools is described in detail as follows:

\section{Speech that contains Acts of Order}

The act of commanding Pragmatically can be defined by the criterion of implying an attitude that Student intends to or intends for the Teacher to take any action for teacher interest after the said action occurs. The action of ordering is prospective, not retrospective (Kreidler, 1998). Second, the speech participants who were fully involved in implementing T were Pt. Meanwhile, the Teacher is the beneficiary of T's action. Meanwhile, the Student is the beneficiary of the Teacher's action. Next, an order has a very high chance of success because its implementation does not have to depend on a condition or approval from the Teacher. The Student can force the Teacher to carry out his orders as the Student wants because the Student has a higher authority than a teacher in the perspective of this connection, 
If it is viewed from the number of standard units or parts that compose it, Pragmatics utterances containing acts of commanding or ordering can have various formal forms of two speech units.

\section{Part 1}

- Teacher: Sing with the children...

- Student :(Sing together)

$A, B, C, D, F, G, H, I, J, K, L, M, N, O, P, Q, R, S, T, U, V, W, X, Y, Z$

- Teacher : Sing Once Again, My students!!

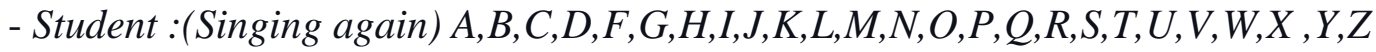

\section{Part 2}

- Teacher: My students follow after me...

Chicken

- Student: Chicken

- Teacher: snakes

- Student: snakes

\section{Speech containing the act of asking}

The act of asking implies the Student's attitude (want to) for the Teacher to do an action T for the Student's benefit.

- Teacher: Before we continue the lesson, do you still remember some songs that have to do with ab. About A,B,C,D,F,G,H,I,J,K,L,M,N,O,P,Q,R,S,T,U,V,W,X,Y,Z .(ask to remember)

- Student: Sing

- Teacher: Okay, how was the song yesterday?

\section{Speeches that contain Acts of Inviting}

From a Pragmatics perspective, inviting is almost the same as the act of asking, especially when viewed from the attitude implied by both parties. Both the act of requesting and asking to suggest that the Student wants (want to) for Pt to take action T. This can also be seen in the implementation aspect of T's action.

- Teacher: Let's open our subject by reading basmalah together,

- Student: "Bissmillahirrohman nirrohim.."

- Teacher: "Come on, Students, open page 34".

\section{Speeches that contain Opening Actions / Greetings}

- Teacher: "Previously, Assalamualaikum warohmatullahiwabarokatuh..".

- Student: "Waalaikumsalam warohmatullahi wabarokatuh..." 


\section{Speech that contains the act of asking questions}

- Teacher: Okay, do you still remember the names of yesterday's animals?

- Student: Still sir

- Teacher: Chicken

- Student: Chicken

- Teacher: Snake

- Student: Snake

- Teacher: Bird

- Student: Bird

\section{CONCLUSION}

Based on the two problems that are the focus of the study, the conclusions drawn from the research findings are as follows:

The speech acts of Pragmatics politeness in the language of the English Teacher at the Islamic elementary school include seven speech acts, namely (1) commanding speech acts, (2) requesting speech acts, (3) inviting speech acts, (4) asking speech acts, (5) the speech act of greeting, (6) the speech act of advising, (7) the speech act of asking for approval, each of these illocutions can be expressed in one or more units.

When viewed from the grammatical mode, politeness speech acts in the English language teacher are generally coded in the Core Speech unit, which can be imperative sentences (active and passive), declarative sentences, and interrogative sentences. Thus, it can be briefly concluded that the form of Pragmatics politeness speech in the English language teacher has many varieties, both in terms of the sub-illocutionary it contains and the number of speech units in the overall structure of the speech. The diversity of Pragmatics politeness structures in the English Teacher's language seems closely related to speech efforts to achieve communication goals, namely conveying meaning effectively and maintaining social relations among speech participants.

\section{REFERENCES}

Altarawneh, M. (2020). A Useful Guide To The Teaching And Testing Of Pragmaticss In The EFL / ESL Classroom. May 2015.

Austin, J.L. (1962). How to do Things with Words. Oxford: Clarendon Press.

Borg, W. R., \& Gall, M. D. (2003). Educational Research (Seventh edition). In Educational Research: An introduction (7th ed.).

Brown, D. H. (2004). Teaching by Principles; An Interactive Approach to Language Pedagogy 
Second Edition (p. 246).

Delahaie, J. (2018). SocioPragmatics competence in FFL language teaching Towards a principled approach to teaching discourse markers in FFL. July, 1-30.

Errington, J.J. (1988). Structure and Style in Javanese: A Semiotic View of Linguistic Etiquette. Philadelphia: University of Pennsylvania Press.

Ellis, E.M. (2002). Language awareness and its relevance to TESOL. 3198, 1-23.

Grice, H.P.(1975). Logic and Conversation. New York: Academic Press.

Gunduz, N. (2019). SocioPragmatics Elements and Possible Failure in EFL Teaching. July. https://doi.org/10.1501/Dilder

Hefner, R.W. (1985). Hindu Javanese. Tengger Tradition and Islam. Princeton, New Jersey: Princeton University Press.

Horn, R.L. \& Ward, G.(2007). The Handbook of Pragmatics. Blackwell Publishing.

Kreidler, C.W. (1998). Introducing English Semantics. London \& New York: Routledge.

Leech, G. (1983). The Principle of Pragmatics. Harlow: Longman Group Limited.

Jacob L. (2001). Pragmatics: An Introduction. (Second Edition). Oxford: Blackwell.

Miles, M.B.\& Huberman,A.M. (1984). Qualitative Data Analysis: A Source Book of New Methods. Beverly Hills, CA: sage Publications.

Richey, R. C., \& Klein, J. D. (2005). Developmental Research Methods: Creating Knowledge from Instructional Design and Development Practice. 16(2), 23-38.

Risang, F. X. (2017). Humanistic Language Learning in the 21 st Century Classroom: A Brief Look at Practice and Application. April, 1-8.

Searle, J.R. (1969). Speech Acts. Cambridge: Cambridge University Press.

Patton, M.Q. (1980).Qualitative Evaluation Methods. Beverly Hills, CA: Sage Publication. Mey,

Kachru.Y\& E. Smith, L.E. (2009). Cultures, Contexts, and World Englishes. 136-138. 